\title{
Introduction: Hunting for Truffles
}

Something about the word "museum" tends to make people feel very slightly dreary, but this is not a dreary museum and all museums, with my thinking, should be places of life and enjoyment and gaiety and fun because that is what education is all about.

S. Dillon Ripley, 1984, at the Peabody Museum

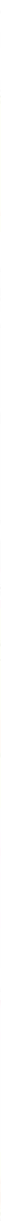


THE SCIENCE AND THE STRANGENESS воTH begin in a parking lot on a busy street in New Haven, Connecticut, outside the Yale Peabody Museum of Natural History. The trees are honey locusts, an unspoken memorial to the mammoths and mastodons that once wandered there, consuming the tough, elongated pods of such trees and spreading their seeds. The vanity plate on the Subaru parked nearby, YPM 228, is the Peabody's catalogue number of a fossil trilobite, Triarthrus eatoni, which wriggled its many limbs 450 million years ago near what is now Rome, New York. (This is vanity of an esoteric variety.) The bumper sticker on another car advises, "Don't believe everything you think."

There was, as I was soon to learn, plenty more strangeness and science - 150 years' worth - inside the walls of the Peabody, together with an abundance of thinking and rethinking about the world. One day, early in my research for this book, a curator proudly pointed out the collection of overeducated tapeworms extracted from incoming Yale freshmen at the beginning of the twentieth century. Also the vial of maggots from a murder victim wrapped in a rug and ... But I changed the subject as quickly as possible to a lovely mobile hanging over a workbench, with a big luna moth the color of translucent jade and a morpho butterfly like a radiant blue sky, along with other moths and butterflies, all as if in flight. The insects were suspended with hairs donated by various staffers, the object being to determine whose hair was the least visible. The winner would gain the right to give up even more hair to make preserved insects airborne for an upcoming exhibit.

To be honest, I love this sort of thing (even the tapeworms). Robert Louis Stevenson once described his boyhood manner of reading as digging "blithely after a certain sort of incident, like a pig for truffles." In his hunger for bright images and bold action, the young Stevenson foolishly skipped past "eloquence and thought, character and conversation," which I think most adult readers would regard as the truffles. But the pig analogy strikes me as exactly right about the oinky, snuffling character of the writer's work, and for me the Peabody Museum was a mother lode of truffles.

One day, for instance, I came across a somewhat plaintive letter about luggage left behind with a U.S. Cavalry lieutenant named A. L. Varney at an outpost in the Wyoming Territory in 1872: "I am still holding the Fossil Mosasaurus for you," the lieutenant wrote to paleontologist O. C. Marsh, "but as I expect to be ordered from this station soon please advise me what to do with it." ${ }^{1}$ This was unclaimed

(Overleaf) Preparator Hugh Gibb (shown here in about 1914) had the immense task of assembling many of Marsh's discoveries for public display, like this Torosaurus skull, and the Pteranodon mounted behind him. 
baggage of a high order, a Mosasaurus being a prehistoric sea monster up to sixty feet in length. Fortunately for Lieutenant Varney, it was just the skull, now safely preserved as YPM.00327.

Another day, in the Historical Instruments Collection, I became fixated on a saliometer - that is, a saliva meter. It was an instrument I had not previously imagined to have existed. It was the one Ivan Pavlov used in his classic conditioning experiments on salivary response in dogs. (Pavlov gave it to Yale psychologist Robert Yerkes, from whom it made its way to the Peabody Museum.) In the Vertebrate Zoology Collection, I became enchanted with the story of the sled dog Togo, hero of a 1925 race to deliver diphtheria antitoxin through impossible weather conditions to a stricken Alaskan community. Togo lives on as the continuing inspiration for the Iditarod Trail Sled Dog Race - but his skeleton is now lovingly preserved in climate-controlled conditions at the Peabody Museum.

Truffle hunting, it turns out, has long been a familiar pursuit to the Peabody Museum staff. A vertebrate paleontologist there once remarked that the best collecting he had ever done was not in the Badlands of the American West nor in Inner Mongolia but in the basement of the Peabody Museum. The discoveries lie waiting even now - not just in the basement but almost anywhere in the cluster of buildings around the main museum as well as in archive and storage facilities in the suburb of West Haven. In 2002, for instance, researchers browsing through the paleontological specimens noticed a distinctive five-inch-long tooth. A Colorado collector had sent it in 1874 to O. C. Marsh, who was too swamped with other specimens to make sense of it. This was regrettable, as it has turned out to be the earliest known specimen of the über-predator Tyrannosaurus rex ("King of the Tyrant Lizards"). Thus Marsh, an intensely possessive and competitive collector, missed out on the discovery, and the species had to wait another thirty-one years to be described - by one of his hated rivals.

Somewhat more humbly, a curator browsing through the botanical collection a few years ago noticed a liverwort specimen marked as the type of its species - that is, the individual by which the species was first described and defined. It looked like a bunch of dried schmutz, as preserved liverworts will do. Then the botanist looked more closely at the identifying tag and found it had been collected by one Charles Darwin during his travels aboard HMS Beagle.

Over 150 years, the Peabody Museum has collected, described, catalogued, and preserved roughly 14 million specimens - representative samples of the Earth, its succession of inhabitants, and the heavens. Many Earths, really, over several billion years. A relative handful of these specimens are on public display. Many more wait for someone to come along, next year or 150 years from now, with the right 


\section{The Mystery of the "Intercostal Clavicle"}

This isn't perhaps what the mercantile banker George Peabody had in mind when he founded his namesake museum in 1866 , nor is it something to which the scientists working there have ever aspired. But the Peabody Museum has, on the side, enjoyed (or endured) a lively career in popular entertainment.

The 1938 screwball comedy Bringing Up Baby, for instance, featured Cary Grant as a mild-mannered paleontologist and Katharine Hepburn as a flighty heiress with a pet leopard named Baby. The plot turns on a Brontosaurus specimen a lot like the one that had recently been mounted at the Peabody Museum. The resemblance was the result of a Hollywood researcher's having come to the Peabody and climbed an eighteen-foot ladder to measure and photograph every bone. In the movie, the hero ends up hunting for a bone that never existed in real life, the "intercostal clavicle." More realistically, he is also desperately seeking a donation from a Mr. Peabody.

The Peabody Museum was also the inspiration for the archetypal king of movie monsters, Godzilla, though at second hand. The art director of the original 1954 Japanese production studied the Peabody Museum's influential Age of Reptiles mural, then a recent cover story in Life magazine, and concocted a creature based on artist Rudolph F. Zallinger's Tyrannosaurus, Iguanodon, and Stegosaurus. (Zallinger's mural also inspired a generation of future paleontologists, possibly with help from Godzilla.)

More recently, in the long-running cartoon series The Simpsons, Yale alumnus and megalomaniacal plutocrat Mr. Burns and a character named Lily Bancroft were revealed to have had sex at the Peabody Museum in a (fictional) diorama of Eskimos and penguins, begetting a child voiced by Rodney Dangerfield.

At this writing, $\mathrm{HBO}$ is planning a series based on the bitter nineteenth-century Bone Wars between archrival paleontologists O. C. Marsh of the Peabody Museum and Edward Drinker Cope of the Academy of Natural Sciences of Philadelphia. One Cope biographer responded to the report that it will be a comedy with a four-letter word: “GACK." 
blend of knowledge, insight, luck, or technology to make sense of them. They wait for someone to whom a drawerful of specimens, silent for ages, may begin to resonate with lost voices and ancient dreams.

"I pound away at my typewriter and squint industriously through my microscope," a paleontology graduate student once wrote to his sister as he studied fossils in the back rooms of the Peabody Museum. "I publish articles and give papers and meet people and try not to laugh, but the moon is always over my shoulder." Then, in four eloquent sentences, the writer, whose name was George Gaylord Simpson, explained the feelings that kept him at it: "The spectacle at which I attend is vastly moving. There is an almost painfully epic sweep to the vastness of geologic ages which pass beneath my fingers in tattered fragments. The commonplace room is always filled with the mute cries of ages impossible to contemplate in which life has blindly toiled upward, or at least to further complication and further ability to realize that it cannot realize anything at all. It is all very strange and thrilling in a way which is, I am afraid, incommunicable." ${ }^{2}$

The people doing this work are no doubt prone to the ordinary (but also engaging) human business of petty resentments and bickering. And yet the work they do, this business of looking at the same specimens over and over, pondering how two bones might once have articulated together or deciphering how a certain plant once lived, is magical. A jigsaw puzzle of broken rock somehow opens a path millions of years into the past. It has the power to resurrect species and re-create worlds. This is what makes the Peabody Museum so appealing for me as a writerand, I hope, for readers as well - especially because the results from work there have often been so profoundly influential.

The Peabody has never been a particularly big museum (its staff currently numbers about eighty-five), and New Haven is not even the biggest city in Connecticut. (Among U.S. cities, it ranks 195th just behind Olathe, Kansas, and Sterling Heights, Michigan.) But it suggests something of the Peabody Museum's outsized influence that it was a major force in creating, at roughly the same moment, both the age of oil and the American conservation movement. It was the Peabody Museum that largely drove the first great age of dinosaur discovery in the nineteenth century. It was the Peabody, more recently, that killed off the image of dinosaurs as plodding and stupid, reinventing them as swift, agile, and even intelligent. It thus set loose a global pandemic of "dinomania," especially among schoolchildren, culminating in the multiple iterations of "Jurassic Park." Researchers from the Peabody Museum have been remaking the world for 150 years, from the introduction of science education in North America to the rise of modern ecology, 
from the first full description of the giant squid to the modern understanding of how feathers evolved, and from the uncovering of the monumental Inca ruins at Machu Picchu to the rise of Caribbean archaeology.

For me as a writer, the story of the Peabody has been irresistible. Two thoughts will, I think, help make it equally compelling to read. The first is a caveat: the scientists who managed these achievements were often brilliant scholars and otherwise admirable, even heroic, in the face of widespread mistrust of science. But until late in the twentieth century, they were also almost exclusively men, and they admitted into their ranks only other scholars who happened to be white, male, Protestant, and preferably members of established Yankee families, or, better still, related by blood or marriage. Of one such professor, whose father was also a professor at Yale, the historian Robert V. Bruce wrote that if he "had been born female, black, or a child of the nineteenth-century American South or frontier West" - or, for that matter, Irish, Asian, Hispanic, Jewish, or an immigrant of almost anywhere other than northern Europe - "it seems unlikely that his genius would have been heard. His social, economic, cultural, geographical, and institutional circumstances did not make him a genius," Bruce continued. ${ }^{3}$ But they made his genius matter and allowed it to flourish. In honoring these men, we should bear in mind the many voices those same circumstances silenced.

There is, however, a tendency now to regard the story of "dead white men" as no longer worth telling and to exaggerate or romanticize the role of people who were ruthlessly excluded from power. To me it makes more sense to relate how history actually happened, bigotry and all, and this book has given me a very personal way to put this in perspective. In the course of my research, I discovered that my great-great-grandfather had been an immigrant laborer in a New Jersey marl pit at the time Marsh recovered a specimen of the sea monster Mosasaurus there. He was the sort of person Marsh would undoubtedly have regarded as beneath notice. And yet I am certain that my forebear, who later died in a collapse at that marl pit, had enough love of learning and of higher things to be proud to be associated with such discoveries. He would also understand that Marsh, not Conniff, is the better story.

The second thought that readers may find helpful is more like an outline of the book's organization. Five overarching stories or themes run through the book and sometimes overlap. Readers may be surprised, first of all, that for the ten opening chapters, the museum does not exist, at least not as a physical structure. But the dream of the museum motivated some of the greatest American scientists of the nineteenth century. James Dwight Dana in particular had spent four years circling the world and gathering specimens with the U.S. Exploring Expedition, at fre- 
quent risk of death, only to see, on his return home, many specimens lost to science because of bureaucratic bungling. He threw his heart and mind into making the Peabody Museum a place where specimens would be preserved as a permanent means of interpreting and understanding the world.

The grandiose personality of O.C. Marsh and the size and strangeness of the fossil animals he discovered dominate much of the book. A few of his collectors also appear here, notably the poker-playing, gun-toting visionary reader of rock, John Bell Hatcher. Marsh's nakedly personal combat with archrival Edward Drinker Cope runs through many chapters, culminating in the very public "Bone Wars" of the 1890s.

Though it often seemed like one man's museum in this era, the Peabody was always more than O. C. Marsh and more than dinosaurs. As the book progresses, I aim to bring this less public museum into the foreground. I confess I initially underestimated the scientists who worked in Marsh's shadow, but I soon found such lesser-known figures as Addison Emery Verrill, George Bird Grinnell, Charles E. Beecher, and Charles Schuchert walking around in my head, highly engaging characters whose contributions to both science and conservation still resonate today. If you are looking at the latest studies of the life around Atlantic seamounts, for instance, you should know that Verrill got there first.

The twentieth century opens with Yale's astonishing 1905 decision to demolish the museum building in the aftermath of some of the greatest scientific discoveries of the nineteenth century. Readers cannot help noticing here, as throughout the book, a paradox: for much of its history, major achievements by the Peabody Museum failed to elicit commensurate support from Yale. This was, I think, partly a product of an academic culture that often glorified intellectual theorizing above the object being theorized about. As an English major, for instance, I often had the impression that literary criticism mattered more than literature. This tendency seemed to be exaggerated when the objects came from the natural world rather than from the human mind. Until the 1950s, and even beyond, Yale also regarded the sciences as a second-class intellectual enterprise - much too hands-on, much too how-to - and the Peabody Museum perhaps more so than the rest. Science taught lessons about humanity that the humanities did not necessarily want to hear. The book also describes the eventual construction of a new museum building after nine years of homelessness and the struggle to figure out how a natural history museum should engage the attention of the public (not to mention the university). The courageous response, just as the 1925 Scopes trial was criminalizing the teaching of evolution, was to organize the Peabody Museum displays entirely on evolutionary lines and to teach evolution to schoolchildren and adults alike. 
Toward the end of the book, I look at two major areas of research that struggled to get equal time or space with paleontology in the Peabody $\mathrm{Mu}$ seum. Anthropology once again put the museum in national headlines when Hiram Bingham came back with his account of the "lost city" of Machu Picchu. George G. MacCurdy and, later, a post-World War II generation of his intellectual grandchildren proceeded to develop anthropology as a serious science. Zoology went through a similar twentieth-century transition, with S. Dillon Ripley and Charles Remington building up major collections in their fields, and G. Evelyn Hutchinson and his students developing the theoretical framework of modern ecology. The book ends, however, as it began, back in paleontology, the study of lost worlds being the Peabody Museum's great strength.

In telling this story, my ambition is not just to explain the science but to let readers experience it for themselves. In that spirit, the place to start is back on the footpath that runs from the parking lot around the front of the Peabody Museum. It's embedded with Big Bird footprints (technically from a theropod dinosaur that walked 110 million years ago in Texas). The path runs through a Cretaceous garden of plants that dinosaurs knew-Allegheny spurge, dwarf mountain pine, cinnamon ferns, and tulip trees - and it loops out and around a model of a huge Torosaurus with gaping jaws, as if waiting to pluck up small children. (No worries, Torosaurus was a vegetarian. Deinonychus, on the other hand ...) It leads the visitor to the entry door and into a lobby where a giant squid wriggles overhead and massive dinosaurs wait to be admired just around the corner.

Please step inside. You may find some truffles. You may hear the mute cry of ages. You may, with luck, end up no longer believing the things you thought when you came in. 